\title{
Percepcija simbola totalitarnih režima — vizualni identitet fašizma, nacizma i komunizma u svjetlu procesa brendiranja
}

Predrag Haramija*

\begin{abstract}
Sažetak
U radu se istražuje percepcija simbola triju totalitarnih režima, odnosno ideologija 20. stoljeća (fašizma, nacizma i komunizma) u svjetlu marketinških spoznaja o procesu brendiranja. Simboli totalitarizma bili su ponajprije orude snažne propagande $i$ indoktrinacije, a razlike u dubini ( $i$ širini) nametanja totalitarnih ideologija spoznaju se iz međuodnosa stranačkih i državnih simbola. Nametanje ideologije i postupci totalitarnih režima utječu na promjenu izvornog značenja simbola koje su koristili. Simboli totalitarnih režima danas se zato uglavnom ne sagledavaju kroz izvorno značenje. Simboli fašizma i nacizma zabranjeni su ili nepoželjni u većini zemalja, a oni komunizma još se slobodno ističu u nizu zemalja. Tek su u rijetkim zemljama zabranjeni. To je zato što su zločini jednih javno osudeni, a drugih nisu. Osuda postupaka učinjenih pod nekim simbolom utječe i na percepciju tog simbola u javnosti.

Ključne riječi: totalitarizam, simboli, vizualni identitet, promidžba, brendiranje
\end{abstract}

\section{Uvod}

Simboli triju totalitarnih režima, odnosno ideologija 20. stoljeća (fašizma, nacizma i komunizma) bili su ponajprije oruđe snažne propagande i indoktrinacije. Svi totalitarni režimi činili su stravične zločine. U ime njihovih ideologija pobijeni su milijuni ljudi. Međutim, percepcija simbola tih totalitarizama u javnosti se razlikuje. Simboli nekih totalitarizma neprihvatljivi su, pa i zabranjeni, u većini zemalja svijeta, a nekih nisu. Je li tomu tako zato što su se neki totalitarizmi uspješnije „brendirali“ ili je riječ o nekim drugim razlozima, pitanje je na koje pokušavamo naći odgovor.

U prvom poglavlju ukazujemo na sličnosti i razlike fašizma, nacizma i komunizma.

* Dr. sc. Predrag Haramija, Zagrebačka škola ekonomije i managementa. Adresa: Jordanovac 110, 10000 Zagreb, Hrvatska. E-pošta: predrag.haramija@zsem.hr 
U drugom opisujemo način na koji pristupamo analizi vizualnog identiteta navedenih ideologija. Ukazujemo zašto spoznaje procesa brendiranja i razlikovanje znaka i simbola smatramo važnim te zašto ključna vizualna obilježja nalazimo na zastavama i amblemima totalitarnih pokreta.

U trećem poglavlju prikazujemo glavne simbole totalitarnih režima, utvrđujemo razloge odabira pojedinih simbola za reprezentanta pojedine ideologije te prosuđujemo učinkovitost tog odabira u smislu persuasivnosti vizualne komunikacije. Istražujemo podudarnost značenja tih simbola i ideologije tih režima te opseg nametanja ideologije kroz međuodnos stranačkih i državnih simbola. Sagledavamo u kojoj mjeri su neki simboli promijenili svoje izvorno značenje zbog njihova korištenja u političke svrhe, odnosno koje su razlike između njihova izvornog (arhetipskog) i pridodanog (ideološko-političkog) značenja. Spoznanja o njihovoj (ne)podudarnosti objašnjavaju značenje koje danas prevladava u javnoj percepciji.

U zaključku prosuđujemo kakvo značenje ti simboli imaju danas, tj. koja im je percepcija u javnosti, odnosno kakav im je učinak sagledan u kontekstu procesa brendiranja.

\section{Svojstva totalitarnih režima}

Totalitarizam je naziv za politički režim koji pokušava kontrolirati gotovo sve aspekte društvenog života i mobilizirati cijelu populaciju da slijedi njegove ciljeve, odnosno ideologije. Totalitaristički režimi postoje i na desnoj i na lijevoj strani političkog spektra.

Prvi pravi totalitarizmi nastaju početkom 20. stoljeća, u kaosu nakon Prvog svjetskog rata. Slom dotadašnjeg europskog poretka (propast triju carstava: njemačkog, austro-ugarskog i ruskog) uzrokovan Prvim svjetskim ratom, društvena, politička i ekonomska kriza koja je uslijedila te opći osjećaj nesigurnosti omogućili su totalitarnim pokretima da preuzmu vlast. Naime, osiromašeno mnoštvo vapilo je za moći i društvenom kohezijom koja će ponuditi izlaz iz krize. Totalitarni pokreti ponudili su frustriranim ljudima viziju veličanstvene budućnosti, pružili im »zaslon od realnosti otporan na činjenice« $\mathrm{i}$ asimilirali ih $\mathrm{u}$ kompaktno kolektivno tijelo (Hoffer, 2002, 61; 163). ${ }^{1}$ U preuzimanju, učvršćenju i održanju vlasti totalitarnim pokretima uvelike pomažu i nove tehnike promidžbe i nova sredstva komunikacije.

Često se totalitarizam pogrješno uspoređuje i izjednačuje s autoritarnim oblicima vladavine (koje nalazimo kroz cijelu povijest i širom svijeta) kao što su diktatura, tiranija, despotizam, autokratski režim itd. Diktature ili autokracije koriste silu da zadrže političku moć, međutim prvenstveno su zainteresirane za

1 Citat u prijevodu autora. Hoffer tvrdi i da je totalitarnim pokretima zajedničko sagledavanje zapadnih demokracija i njihovih vrijednosti kao dekadentnih, a ljudi u njima »premekanim, previše sklonim užicima i previše sebičnima da bi bili skloni žrtvovati se za viši cilj« (Hoffer, 2002, 122). U očima tih pokreta to znači unutarnje moralno i biološko propadanje. 
vlastiti opstanak, a ne ideologiju. Nasuprot tomu, za totalitarni režim politička moć je sredstvo kojim želi promijeniti svijet i ljudsku prirodu. Svoju ideologiju nameće cijelomu društvu te zahtijeva da ni jedan pojedinac ili organizacija ne može biti izvan obuhvata te ideologije. Tako ideologija prožima sve strukture društva i možemo reći da totalitarna vlast nastoji u potpunosti kontrolirati ne samo djela nego i misli svojih građana.

Hannah Arendt tvrdi da su nacistički i komunistički režimi bili novi oblici vlasti, a ne samo ažurirane verzije starih tiranija. Izvor utjecaja na mase im je ideologija, koja pruža utješan, jednostavan odgovor na tajne prošlosti, sadašnjosti i budućnosti. Za nacizam, sva povijest je povijest borbe rasa, a za marksizam, sva povijest je povijest borbe klasa. Nakon što je premisa prihvaćena, sve aktivnosti države mogu se opravdati pozivanjem na zakone prirode ili zakone povijesti, koji opravdavaju osnivanje autoritarnog državnog aparata (Arendt, 1951, 461-469).

Karl Dietrich Bracher suštinu totalitarizma vidi u zahtjevu za potpunom kontrolom i preobrazbom svih aspekata društva udruženom sa sveprožimajućom ideologijom, sustavom vrijednosti koji podupire autoritarno vodstvo te zajednički identitet države i društva. Na taj način razdvaja se totalitarno „zatvoreno“ razumijevanje politike od „otvorena“ demokratskog razumijevanja (Bracher, 1981, 21).

Friedrich i Brzezinski tvrde da svaki totalitarni sustav ima sljedećih šest, definirajućih i međusobno podupirućih, karakteristika: (1) razrađena vodeća ideologija, (2) samo jedna masovna stranka, obično na čelu s diktatorom, (3) sustav terora koji koristi sredstva poput nasilja i tajne policije, (4) monopol na oružje, (5) monopol nad sredstvima komunikacije, (6) središnje usmjeravanje i kontrola gospodarstva putem državnog planiranja (Friedrich i Brzezinski, 1967).

I niz drugih znanstvenika smatra da totalitarizam za glavni cilj ima mobilizirati cijelu populaciju u podršci službene državne ideologije, netolerantan je prema aktivnostima koje ne prate ciljeve države te podrazumijeva represiju ili državni nadzor svih segmenata društva (Armstrong, 1961; Bernholz, 2001; Gleason, 1995; Kershaw, 1992; Payne, 1996; Pipes, 1995; Sauer, 1967; Schapiro, 1972). Svi oni slažu se da je totalitarizam u najpotpunijoj varijanti ostvaren u SSSR-u i nacionalsocijalističkoj Njemačkoj jer su se oba temeljila na sveobuhvatnoj kontroli i prožimanju svih sektora društva, na ideologiji, promidžbi, teroru i koncentracijskim logorima.

Kao pravi totalitarni režimi najčešće se spominju fašizam, odnosno Italija za Benita Mussolinija od 1922. do 1943., nacionalsocijalizam, odnosno Njemačka pod Hitlerom od 1933. do 1945., i komunizam, odnosno Sovjetski Savez pod Staljinom od 1928. do 1953. godine. ${ }^{2}$

2 Kao totalitarni režimi 20. stoljeća u literaturi se znaju navoditi i Španjolska za Francisca Franca, Portugal za Antónija de Oliveira Salazara, Narodna Republika Kina za Mao Zedonga, Sjeverna Koreja pod Kim Il Sungom (i nasljednicima), Kuba pod Fidelom Castrom, Kambodža za Pol Pota, Rumunjska pod Nicolaeom Ceaucescuom i Irak pod Saddamom Husseinom. Prema šest kriterija koje navode Friedrich i Brzezinski i SFRJ pod Josipom Brozom Titom nedvojbeno spada u totalitarne režime. 
Uz brojne sličnosti (u strukturi i postupcima vlasti) postoje i razlike. Očituju se ponajprije u ideologiji koja se nameće, a razvidne su i u načinu dolaska na vlast te trajanju pojedinih režima, odnosno ukorijenjenosti ideologije.

\subsection{Fašizam}

Fašizam je naziv za politički režim u Italiji od 1922. do 1945., a koristi se i za slične režime, odnosno ideologije, nastale u nizu europskih država dvadestih i tridesetih godina 20. stoljeća.

Fašisti na vlast u Italiji dolaze „maršem na Rim“ 1922., kojim prisiljavaju kralja Viktora Emanuela III. da Benita Mussolinija (1883.-1945.) postavi na čelo koalicijske vlade. On je ubrzo uredio izvanredne ovlasti za vladu. Novim izbornim zakonom osigurao je 1924. za svoju stranku dvotrećinsku većinu u parlamentu. Potom je Zakonom o proširenju prava izvršne vlasti 1925. dobio neograničenu vlast - postao je diktator, tj. duce (vođa). Veliko fašističko vijeće srušilo je 25. srpnja 1943. Mussolinija, a zatim ga uhitilo i interniralo. Talijanski fašizam propao je vojnim porazom u travnju 1945. godine.

Suština ideologije fašizma promicanje je države kao središnje vrijednosti i njezino prvenstvo u odnosu na volju i prava pojedinca. Opravdava se autoritarno vodstvo i nužnost hijerarhije te poslušnost karizmatičnomu vođi, koji utjelovljuje državu. Uzvisuje se borbenost i ratničke vještine, a omalovažavaju stare građanske vrijednosti.

\subsection{Nacionalsocijalizam}

Nacionalsocijalizam ili nacizam (njem. Nationalsozialismus ili skraćeno Nazismus) nastao je u Njemačkoj nakon Prvog svjetskog rata u okrilju Nacionalsocijalističke njemačke radničke stranke (Nationalsozialistische Deutsche Arbeiterpartei - NSDAP).

Nakon što je Velika depresija zahvatila Njemačku, nacisti su na izborima 1932. postali najveća stranka u Reichstagu. Godine 1933. Adolf Hitler (1889.-1945.) je položio službenu zakletvu za kancelara Reichstaga te ubrzo zadobio apsolutnu vlast. Time je nacizam prerastao u vladajuću državnu političku doktrinu. Nakon ratnog poraza 1945. nacistički vođe osuđeni su kao ratni zločinci.

Ideologiju Nacionalsocijalističke njemačke radničke stranke (NSDAP) Hitler je izložio u djelu Mein Kampf („Moja borba“). Svojstven joj je integralni nacionalizam i rasizam, naučavanje o nadmoći arijevske rase i potrebi istrjebljenja nižih rasa, podređenost pojedinca državi i neupitna poslušnost vođama, teritorijalno širenje. Nacionalsocijalistički svjetonazor sustavno je ulazio u sva područja života putem potpune kontrole medija, odnosno iznimno snažnom promidžbom (koju je osmislio i vodio J. Goebbels). 


\subsection{Komunizam}

Komunizam je naziv za politički pokret koji obuhvaća ukupnost komunističkih partija, organizacija i skupina u svijetu, odnosno politički sustav totalitarne (jednostranačke) vlasti komunističke partije.

Godine 1917. u Rusiji je, nakon Listopadske revolucije, na vlast došla boljševička partija pod Lenjinovim vodstvom. Tako je uspostavljen prvi komunistički režim u svijetu (tzv. diktatura proletarijata). Slijedila je radikalna agrarna reforma i podržavljenje industrije, trgovine i banaka, zabranjene su sve stranke i uvedena jednostranačka vladavina. SSSR je, posebice u Staljinovo doba (1922.1953.), bio izrazito totalitarni poredak. Kao i nacizam, odlikuje ga kult ličnosti, partijska diktatura i sustavno nametanje partijske ideologije u svim segmentima društva, teror tajne policije i uspostavljanje radnih logora. Ipak, razlikuje se od nacizma, u kojem se teror provodi u ime (arijske) rase, po tome što se u SSSR-u državni teror provodi u ime (radničke) klase. Nakon Drugog svjetskog rata, pod utjecajem SSSR-a, komunizam se proširio te postao vladajući politički sustav i ideologija u državama srednje i istočne Europe te u velikom dijelu Azije i Afrike.

Ideologija komunizma temelji se na ideji savršenog, besklasnog društva potpune jednakosti ljudi, koje bi se trebalo ostvariti po ukidanju privatnog vlasništva i temeljiti na uspostavi zajedničkog vlasništva nad sredstvima za proizvodnju. Kao ideologiju i pokret komunizam su polovicom 19. stoljeća utemeljili Karl Marx i Friedrich Engels. Terminom komunizam označavali su besklasno društvo budućnosti, a terminom socijalizam prvu, nižu fazu uspostave takva društva. Svoju radikalnu političku skupinu, osnovanu 1847., nazvali su Savezom komunista.

Od totalitarizama komunizam je najdugovječniji. Započinje (u Rusiji) 1917. te je trajao gotovo do kraja stoljeća, a u nekim zemljama opstoji još i danas. Fašizam i nacizam trajali su znatno kraće od komunizma, 20 i 12 godina.

\section{Pristup tumačenju percepcije simbola totalitarnih režima u kontekstu procesa brendiranja}

Brendiranje je naziv za niz promidžbenih djelatnosti kojima se želi stvoriti image. ${ }^{3}$ Danas gotovo da nema korporacije, tvrtke, organizacije, ustanove, političke stranke, pa ni grada ni države koja se ne nastoji brendirati. Suština je tog procesa u činjenju neke organizacije prepoznatljivom i poznatom u javnosti te povezanje čitavog niza pozitivnih asocijacija s tom organizaciji.

Proces stvaranja brenda uključuje niz postupaka, među kojima su dva glavna koraka: (1) odrediti željeni image (dojam kakvim želimo da nas drugi vide) i (2)

3 Pod anglizmom image obično se podrazumijeva »slika, osjećaj ili asocijacija koja se stvara u čovjekovoj svijesti pri viđenju ili spomenu nekog subjekta (Skoko, 2004, 23). Image neke države ili političke stranke je »ukupnost vjerovanja, predodžbi i dojmova ljudi« (Kotler i dr., 1997, 16). 
u skladu s tim dojmom odrediti vizualni identitet, tj. simbole (znakove, boje) koji će nas predstavljati, i verbalni identitet, tj. poruke koje ćemo publici odašiljati.

Brendiranje se u velikoj mjeri povezuje s izgradnjom željenih asocijacija $u$ svijesti ljudi, a snažno sredstvo te izgradnje je vizualni identitet. Koncentrat vizualnog identiteta svake organizacije u njenom je znaku, amblemu ili logu (u slučaju države u zastavi i grbu). Ovisno o uspješnosti procesa brendiranja, javnost poznaje taj znak. ${ }^{4}$ Neki autori smatraju da je baš znakovlje koje su stvorili ili koristili totalitarni režimi ključni aspekt i temelj učinkovitosti njihove promidžbe, odnosno uvjerljivosti vizualne komunikacije (Heller, 2008, 240).

Unutar vizualnih obilježja totalitarnih režima, usmjeriti ćemo se na dva glavna komunikacijska sredstva: zastavu i amblem ili grb, analizirajući simboličko značenje likova i boja koje se koriste kao elementi prikaza na njima. Podsjećamo na bitnu karakteristiku totalitarnih pokreta ili stranaka — nametnuli svoju ideologiju cjelokupnoj populaciji. Upravo kroz odnos elemenata vizualnog identiteta totalitarne stranke i države možemo prosuditi kolika je bila uspješnost u ostvarenju tog cilja. Smatramo da istovjetnost stranačkog i državnog znakovlja, kad neka stranka uspije svoje znakove nametnuti kao državne, ukazuje na najveći opseg nametanja ideologije.

Važno je spomenuti da su fašizam, nacizam i komunizam svoje oznake kreirali preuzimajući već postojeće simbole.

Nerazlikovanje simbola od znaka vrlo je učestalo. Znak može biti svaki fenomen (geometrijski oblik, predmet, pojava, životinja) kojemu je društveno ili kulturalno pripisano neko značenje. Međutim simboli imaju šire i dublje značenje od znakova (oznaka, signala, amblema, loga). Znak obično ima samo jedno značenje, a simboli se odlikuju bogatstvom tumačenja smisla i značenja. Ona su višestruka, fluidna, raznolika, slojevita, složena i često se temelje na metaforičkim asocijacijama koje postavljaju analogiju između stvari iz različitih konteksta, u normalnim okolnostima teško spojivih (Firth, 1973; Leach, 1976).

Duboko psihološko značenje simbola, odnosno njihova primjena u interpretaciji zbivanja u ljudskoj podsvijesti, predmet je istraživanja analitičke psihologije, ${ }^{5}$ koja simbol strogo razlikuje od pojma običnog znaka: »Znak je svagda manji od pojma koji predstavlja, dok simbol uvijek znači nešto više od njegova očiglednog i izravnog značenja. Štoviše simboli su prirodne spontane tvorevine«(Jung, 1974, 55). Značenje simbola nije postojano. Ono je fluidno i različito je u odnosu na prostor, vrijeme, kontekst u kojem se nalazi i na način kako i za što se koristi. Neki drevni simboli promijenili su svoje značenje, a neki novi simboli tek nastaju iz znakova. Znak izlazi iz svoje jednoznačnosti i postaje simbol kad se uz njega veže niz asocijacija.

4 Danas svaka korporacija ima svoj znak (logo), a najuspješnije su one kojima je logo poznat skoro svakomu stanovniku svijeta. I svaki politički entitet (stranka, država, regija, grad) želi biti prepoznatljiv i poznat te vezan s nizom željenih asocijacija.

5 Analitička (kompleksna ili dubinska) psihologija, koju je elaborirao Carl Gustav Jung, psihološka je teorija, ali i metodologija kojom se istražuju dinamičke i psihološke strukture čovjekova ponašanja. 
Sagledamo li to u kontekstu procesa brendiranja, možemo zaključiti da, postane li znak neke organizacije simbol (s nizom pozitivnih asocijacija), on je uspio. Primjerice cilj je tvrtke Mercedes od svojeg znaka stvoriti simbol luksuza i kvalitete, a Coca-Cole simbol sreće, radosti i energije. Ukratko, cilj je procesa brendiranja pretvoriti znak (logo) u simbol. Vezati uz njega niz (pozitivnih) asocijacija.

Često se zaboravlja da sve što neki entitet (gospodarski ili politički) čini, a ponekad i ne čini, šalje poruku o njemu. Uzalud svi promidžbeni napori ako neki entitet svojim postupcima razočara. Zato su dva glavna pitanja u vezi s brendom: je li ikad iznevjerio očekivanja i je li usmena predaja o njemu pozitivna ili negativna. Ovisno o tome znak nekog brenda može postati simbol kvalitete ili nekvalitete, sreće ili nesreće, dobra ili zla.

S obzirom na to da su fašizam, nacizam i komunizam uzeli za svoje oznake već postojeće simbole, možemo govoriti o tri razine percepcije, odnosno tri načina tumačenja simbola totalitarizma:

1. izvorno značenje, povijesno (za analitičku psihologiju — arhetipsko) značenje simbola;

2. namjeravano značenje, sugerirano ideološko-političko značenje;

3. posljedično značenje, nastalo uslijed postupaka režima koji su simbole koristili.

\section{Ključni simboli totalitarnih režima i njihovo značenje}

\subsection{Fašizam}

Fašistički pokret u Italiji inspirirao se organizacijom, snagom i veličinom Rimskog Carstva. Benito Mussolini želio je obnoviti rimsku tradiciju i time pozvati na jedinstvo Talijana pod fašizmom (Griffin i Feldman, 2004, 207). Glavni simbol fašizma u Italiji od 1921. bio je fasces (tal. Fascio, snop uvezanih štapova iz kojeg strši sjekira,) a i sam fašizam dobio je naziv po njemu (Heller, 2008, 240). Fasces je u starom Rimu bio simbol vlasti, moći i pravde, simbol moći koji su nosili liktori koračajući ispred gradskih magistrata (sudaca). ${ }^{6}$

Uvezani snop pruća simbol je jedinstva i zajedništva. Jedan prut je lako lomljiv, no više njih zajedno već je teže polomiti, što u prenesenom značenju govori da je jedan čovjek slab, a zajednica je jaka i izdržljiva. Sjekira je pak »simbol srdžbe [...] ona je amblem snage, razbija i cijepa [...] oruđe za žrtvovanje [...] ona je [...] i simbol diferencijacije« (Chevalier i Gheerbrant, 1983, 597). Sjekira je kroz povijest dobro poznato sredstvo izvršavanja smrtne kazne (odsjecanjem glave). Sve u svemu, fasces je simbol jasne poruke: „snaga naše države počiva u jedinstvu, tko nije uz nas bit će kažnjen“.

6 Prije nego su ga usvojilili talijanski fašisti, simbol fasces bio je korišten i od strane talijanskih političkih organizacija različitih političkih ideologija (u rasponu od socijalističkog do nacionalističkog), kao simbol snage kroz jedinstvo. 
Zastava Fašističke nacionalne stranke (Partito Nazionale Fascista - PNF) od 1926. do 1943. bila je crna sa smeđebijelim simbolom fasces na njoj. Talijanski fašizam koristio je crnu boju i na uniformama svoje paravojske (crnokošuljaši). Crna boja ima snažno simboličko značenje, često negativnih konotacija, »povezuje se s iskonskim tminama, s prvobitnim nediferenciranim stanjem [...] crno se povezuje s zlom, tj. sa svime što ometa i usporuje razvoj po volji božjoj [...] Crno upija svjetlost, ne odbija je [...] evocira kaos, ništavilo, mračno nebo, zemaljske noćne tmine, zlo, tjeskobu, tugu, neizvjesnost i smrt [...] to crno što se povezuje sa zlom i nesvjesnim nalazimo, primjerice, u izrazima: imati crne namjere, crna duša, crni roman [...] Kako crno evocira smrt nalazimo ga kao boju žalobne odjeće« (Chevalier i Gheerbrant, 1983, 76-78).

Ostali simboli koje koriste talijanski fašisti bili su orao (aquila), kapitolijska vučica i kratica SPQR, svi preuzeti iz antičke rimske kulturne povijesti, koju su fašisti pokušali uskrsnuti (Griffin i Feldman, 2004, 207; Payne, 2005, 90).

Fašistička vlada je još 1926. pokušala redizajnirati talijansku zastavu, tj. zastavu Kraljevine Italije, ${ }^{7}$ tako da u nju unese fasces. Međutim, taj pokušaj naišao je na snažan otpor javnosti i talijanskih monarhista i nije uspio. Od tada su na javnim ceremonijama isticane zajedno i zastava Kraljevine Italije i crna fašistička zastava (Mack, 1989, 265; Gentile, 1996, 119; Berghaus, 1996, 90).

Usporedimo li simbole talijanske fašističke stranke i simbole talijanske države, možemo zaključiti da fašistički pokret nije u Italiji uspio nametnuti svoje simbole kao one državne.

\subsection{Nacizam}

Njemački nacizam odnosno nacionalsocijalizam bio je različit od talijanskog fašizma u tome što je bio eksplicitno rasističke naravi. Zato je prvo pokušao prioritet dati preuzimanju simbola svojstvenih arijskoj rasi, tj. onih iz drevne nordijske mitologije. ${ }^{8}$ Međutim, zbog nedostatne prepoznatljivosti takvih simbola, velik dio vizualnog identiteta preuzeo je iz talijanskog fašizma, odnosno iz antičkog Rima (scenografija masovnih skupova, rimski pozdrav ispružene ruke, nošenje starorimskih oznaka - standarda za vrijeme nacističkih skupova te tendencije ka rimskoj monumentalnosti i grandioznosti u arhitekturi).

Najvažniji simbol nacizma ipak se uvelike razlikuje od onog talijanskog fašizma (fasces). Nacistička je zastava i partijski amblem crni kukasti križ (svastika) u bijelom krugu na crvenoj podlozi.

7 Kraljevina Italija (talijanski: Regno d'Italia) bila je država koja je nastala 1861. godine ujedinjenjem Italije. Ta država pod vodstvom savojske dinastije službeno je postojala sve do 1946. godine, kad je monarhiju zamijenila republika. Talijanska zastava bila je prerađivana mnogo puta, ali sve inačice sadržavale su crvenu, bijelu i zelenu boju. Sredinom 20. stoljeća uklonjen je grb koji je 85 godina krasio talijansku zastavu. Najraširenija teorija o talijanskoj zastavi je da svaka boja predstavlja jednu od tri kršćanskih vrlina: zelena nadu, bijela vjeru i crvena milostinju.

8 "Simbole“ je tumačio mistik Guido von List, a Heinrich Himmler ih je uveo u oznake postrojbi (primjerice stilizirani simbol dvostruke rune sig za znak postrojbi SS) (Parkins, 2002, 178.). 
Adolf Hitler 1920. osobno je dizajnirao ključna vizualna obilježja i zastavu Nacionalsocijalističke njemačke radničke partije (NSDAP), odnosno nacističke Njemačke. Znakovlje svojeg pokreta, odnosno ideologije, smatrao je najvažnijim elementom promidžbe. U svojoj knjizi Mein Kampf („Moja borba“) na čak šest stranica opisuje kako je promišljao dizajn nacističke zastave (Hitler, 1993, 488-493). Kazuje da zastava mora biti

simbol naše vlastite borbe, a s druge strane i pokazivati snažno plakatno djelovanje [...] Svi nacionalsocijalisti, svi mi, u našoj zastavi vidimo i naš program. U crvenom vidimo socijalne ideje pokreta, u bijelom nacionalsocijalističke, u kukastom križu misiju borbe za pobjedu arijskog čovječanstva, a istovremeno s njim i pobjedu ideje stvaralačkog rada, koji je sam vječno bio antisemitski, a antisemitski će i ostati (Hitler, 1993, 491-492).

Na Salzburškom kongresu 7. kolovoza 1920. ta je zastava postala službeni amblem Nacističke partije, a po Hitlerovu osvajanju vlasti i državna zastava.

Kukasti križ (njem. Hakenkreuz) ili svastika (od sanskrt. svasti, sreća, dobrobit, zdravlje) križ je sa četiri jednaka kraka, od kojih svaki završava produžetkom pod pravim kutom. Produžetak može biti usmjeren u smjeru kazaljke na satu ili u suprotnom smjeru.

Za svastiku su njemački nacisti tvrdili da je drevni simbol arijevske rase, međutim, nalazimo je u najrazličitijim kulturama već od neolitika.

Svastika je jedan od najraširenijih i najstarijih simbola. Susrećemo ga zapravo od dalekoistočne Azije do Srednje Amerike, u Mongoliji, Indiji i sjevernoj Europi. Bio je poznat Keltima, Etrušćanima, staroj Grčkoj, i od njega je izveden ornament što se naziva grčkim [...]. Svastika je jedan od najvišeznačnijih simbola koji su brojne civilizacije prihvatile kao glavni znamen. Svastika simbolizira okomitu osovinu kotača sa četiri kraka, kojega je kružno kretanje prikazano zavrnućem svakog pojedinog kraka [...] simbol tvoračkog vrtloga oko kojega se stupnjevito raspoređuje hijerarhija stvorenja što emaniraju iz njega [...] ona je simbol nastajanja univerzalnih ciklusa, tokova energije: ne ovosvjetske, nego djelovanja principa na pojavnost (Chevalier i Gheerbrant, 1983, 661).

U budizmu i hinduizmu svastika je simbol stvaralačkih energija, kreativnog ciklusa, simbol koji bi trebao nositelju donositi sreću. Vjerojatno pod utjecajem tih religija svastika je tijekom 19. i početkom 20. stoljeća, vrlo često korištena u zapadnim zemljama sa značenjem sličnom onomu koje imaju prikazi djeteline s četiri lista i potkove. ${ }^{9}$ Svastika je danas u velikom dijelu svijeta ponajprije sinonim za nacizam i zlo. Primjer je promjenjivosti značenja simbola. Drevni simbol u kratkom vremenu u potpunosti je promijenio svoje značenje — od simbola sreće postao je simbolom nesreće i stradanja milijuna ljudi.

9 Do Drugog svjetskog rata nalazimo je kao česti motiv na razglednicama i čestitkama, njemačkim, britanskim i američkim. Svastika krasi i britanske ratne kupone iz Prvog svjetskog rata. Brojni američki, ali i ostali svjetski sportaši, često su znali na dresovima nositi znak svastike. Svastiku nalazimo i na omotima žvakaćih guma i na logu danske pivovare Carlsberg (Tatić, 2015; Arbanas, 2012). 
Grb Njemačke je crni orao na žutoj (zlatnoj) pozadini, s crvenim kljunom i kandžama. Još od antičkog Rima, orao je (uz lava) zacijelo najčešće korišteni motiv u heraldici. Mnoštvo je plemićkih grbova, a i državnih zastava i grbova, koji na sebi imaju lik orla. Kao što je lav „kralj životinja“, orao je „kralj ptica“ te predstavlja snagu, brzinu i nepobjedivost. Nalazimo ga u grbu Svetog Rimskog Carstva u više varijanti, a bio je i grb Njemačkog Carstva od 1871. do 1918. godine. Nakon Prvog svjetskog rata, Weimarska Republika usvojila je sadašnji oblik. 1935. godine Hitler je izmijenio njemački grb tako da je orla restilizirao i u kandže mu stavio hrastov vijenac unutar kojega je kukasti križ. Učinio ga je istovjetnim s amblemom nacističke stranke. Jedina razlika amblema NSDAP i državnog grba je to što orao na amblemu NSDAP (Parteiadler) gleda udesno, a orao na državnom grbu (Reichsadler) ulijevo.

Identificirajuća boja pripadnika nacističkog pokreta je smeđa (smeđe košulje paramilitarnih skupina SA), odnosno crna (pripadnika postrojbi SS). Simboličko značenje smeđe boje nalikuje onomu crne (vidi fašizam): »Smeđe je boja njive, gline i zemljinog tla. Podsjeća na uveo list, jesen i tugu. Smeđa je boja opadanja i kao neki loš spoj čistih boja [...] smeđa je boja simbol poniznosti i siromaštva« (Chevalier i Gheerbrant, 1983, 610).

Nacionalsocijalizam je u Njemačkoj uspio proširiti svoju ideologiju toliko da je svoje simbole nametnuo kao državne. Ideologija jedne stranke postala je tako službena državna ideologija. Međutim, iako su neke države (saveznice Njemačke u Drugom svjetskom ratu) prihvatile ideologiju nacizma (pa i rasne zakone), u njihovom znakovlju ne pronalazimo simbole njemačkog nacizma. I razni fašistički pokreti koji su u to vrijeme postojali u Europi nisu kopirali njemačke simbole, nego su razvili vlastite.

\subsection{Komunizam}

Komunizam, za razliku od fašizma ili nacizma, ne traži uzore u povijesti. To bi bilo suprotno doktrini dijalektičkog materijalizma, odnosno „povijesnim procesima“. On je smatran novom, završnom fazom razvoja čovječanstva. Zato se njegovo znakovlje predstavlja kao nove simbole povezane s radničko-seljačkom emancipacijom. Srp i čekić, (crvena) petokraka zvijezda i općenito crvena boja tri su glavna elementa komunističke ikonografije.

Sva ta tri glavna elementa sadržani su u grbu SSSR-a. Čekić i srp na vrhu su globusa u sunčanim zrakama, okruženi klasjem žita i pod petokrakom zvijezdom s natpisom: „Proleteri svijeta, ujedinite se!“ Globus na grbu najavljuje širenje komunizma cijelim svijetom. Grb je službeno usvojen 6. srpnja 1923. na Drugom zasjedanju Centralnog izvršnog komiteta (CIK). ${ }^{10}$

Srp i čekić vide se kao simboli nužnosti zajedništva („od buržoazije obespravljenih“) seljaka (srp) i radnika (čekić) u čijem se interesu (a protiv buržoazije) pro-

10 Postoje stajališta da je taj grb nastao temeljem javnog natječaja održanog odmah po pobjedi revolucije 1917. po naredbi Vladimira Iljiča Lenjina, a kao pobjednički dizajner spominje se Evgenija Ivanovića Kamzolkina (Wharton, 2007). 
vodi revolucija i međunarodno proletersko jedinstvo. Simbol su preuzeli mnogi komunistički pokreti širom svijeta, neki s lokalnim varijacijama.

Simboličko značenje srpa i čekića dublje je i različitije od onog koje mu pridaju revolucionari: »Malj i čekić unekoliko su slike zla i grube sile. Simbolički se, naprotiv, povezuju s nebeskom djelatnošću, s kovanjem munje. Malj je oružje nordijskog boga oluje Thora [...] i oruđe hromog boga kovačkog umijeća Hefesta [...] Malj u isti mah stvara i razara, on je oruđe života i smrti. [...] On je znak vlasti kojim maše desna ruka, aktivna strana koja se odnosi na djelatnu energiju i na moralnu odlučnost što vodi praktičnom ostvarenju« (Chevalier i Gheerbrant, 1983, 384). Srp nije samo obilježje seljaštva:

Srp simbolizira ciklus žetvi koje se ponavljaju, smrt i nadu u ponovno rođenje [...] Srp je atribut i smrti i vremena što sve uništava. Kronovo je oruđe kojim on odsijeca svom ocu Uranu spolne organe, da bi zaustavio daljnje stvaranje [...] U tom pogledu on je simbol oštre odluke, odlučnog razdvajanja na putu individualnog ili kolektivnog razvitka [...] Taj je simbol očigledno bipolaran: označuje i smrt i žetvu [...] Kad je srp u Saturnovim rukama, gdje se ponekad zamjenjuje s kosom, tada nalazi ovdje svu svoju podvojenost [...] U Saturnovim rukama srp postaje simbol onoga što siječe život [...] slika je smrti (Chevalier i Gheerbrant, 1983, 626).

Crvenu boju komunisti sagledavaju kao boju revolucije, boju krvi koju su hrabri revolucionari spremni proliti za ostvarenje revolucionarnih ciljeva. Simboličko značenje crvene boje (u okviru zapadne civilizacije) ima izvjesne sličnosti.

Boja vatre i krvi, crveno je za mnoge narode prva boja, jer je najdublje povezano s principom života [...] Centripetalno, noćno crveno, boja je središnje vatre čovjeka i zemlje i alkemističkog atanora u kojemu se kuha, dozrijeva i obnavlja se biće ili djelo [...] ono je tajna, misterij života skriven na dnu tmina [...] To je boja duše, libida, srca [...] Plamenocrvena boja nije samo simbol žarke ljubavi nego i boja ratne zastave i osvajanja [...] Ratnici i osvajači kite se crvenim (Chevalier i Gheerbrant, 1983, 79).

Petokraka crvena zvijezda zamišljena je kao simbol pobjedničke vojne sile koja osigurava provedbu revolucije. Od 1917. godine u sovjetskoj heraldici, simbolizira Crvenu armiju i vojnu službu, za razliku od čekića i srpa koji simboliziraju rad. Najčešće se navodi kako su se ruske trupe, koje su pobjegle s austrijskih i njemačkih fronti u Moskvu 1917., pomiješale s lokalnim moskovskim garnizonom. Da bi razlikovali pripadnike moskovskog garnizona od pridošlica, časnici su im dali kositrene zvijezde da nose na kapama. Kad su se pak te postrojbe pridružile Crvenoj armiji i boljševicima, obojili su svoje zvijezde u crveno. Navodi se i da su, neposredno nakon Listopadske revolucije, svi redovi treće petrogradske pukovnije oznake na svojim carističkim kapama zamijenili crvenom zvijezdom (Khvostov, 1996).

Petokraka zvijezda vrlo je često korišten simbol. Na zastavi EU krug je zlatnih zvijezda, a na zastavi SAD niz bijelih. Simboličko značenje joj je snažno.

Zvijezde su simboli duha, a napose simboli između duhovnih snaga ili svjetlosti i materijalnih snaga ili mraka. Prodiru kroz tamu kao svjetla uperena u noć nesvjesnog [...] Plamena petokraka zvijezda simbol je središnjeg očitovanja svjetlosti, mističkog središta i žarišta univerzuma u ekspanziji (Chevalier i Gheerbrant, 1983, 813). 
Pentagram (petokraka zvijezda) simbol je ljudskog mikrokozma [...] ne javlja se samo kao simbol spoznaje nago kao i sredstvo vračanja i stjecanja moći [...] petokraka zvijezda u masonskoj se predaju naziva plamenom zvijezdom [...] ona je amblem genija koji dušu uzdiže do velikih stvari [...] izražava neku moć koja je stvorena sintezom komplementarnih sila (Chevalier i Gheerbrant, 1983, 495).

U crvenoj boji koristi se u komunističkim zemljama i ideološko političko značenje je sasvim jasno: ako u simboličko značenje zvijezde unesemo crvenu boju, onda ona označava čovjeka-revolucionara, ratnika, pobjednika koji donosi komunizam. U tom smislu ona je daleko snažnijeg vizualno-komunikacijskog učinka nego srp i čekić. Mogli bismo sažeto reći da srp i čekić predstavljaju ideologiju komunizma, a crvena zvijezda (nasilnu) provedbu te ideologije.

Komunistička partija je, ne samo u Rusiji, nego i u nizu drugih država, uspjela u potpunosti nametnuti svoju ideologiju, pa tako i svoje simbole nametnuti kao državne. U zastavama i grbovima tih država uvijek nalazimo crvenu zvijezdu ili srp i čekić ili oboje. Da ne govorimo o zastavama vladajućih (komunističkih) stranaka u tim državama - one su gotovo uvijek potpuno iste: crvene s srpom i čekićem.

\section{Zaključak}

Razlike u dubini (i širini) nametanja totalitarnih ideologije možemo detektirati iz međuodnosa stranačkih i državnih simbola.

Talijanski fašizam osvojio je vlast, no nije uspio nametnuti svoje simbole kao državne. Proces brendiranja nije dovršen.

Njemački nacionalsocijalizam po osvajanju vlasti uspio je nametnuti svoje simbole kao državne, ali ih nije uspio proširiti na druge države (pa ni na one koje je osvojio). U tom smislu možemo reći da se nacizam uspješno brendirao u Njemačkoj, no nije uspio van njezinih granica.

Komunizam je osvojio vlast te nametnuo svoje simbole kao državne simbole u Rusiji, ali i u nizu drugih država svijeta. U tom smislu komunizam je jedina od tri totalitarne ideologije koja se elementima svojeg vizualnog identiteta uspjela globalno proširiti kao brend. Možemo reći da se komunizam najuspješnije brendirao - postao globalni brend. To je zato što je on bio najdugovječniji od svih totalitarnih režima i imao je najviše vremena za brendiranje svoje ideologije. Svi ostali totalitarizmi bili su odmah nakon Drugog svjetskog rata javno osuđeni, a on je nastavio širiti svoj utjecaj širom svijeta.

I u odnosu na tri razine percepcije, odnosno tri načina tumačenja značenja simbola totalitarizma, ustanovljene su razlike među totalitarnim režimima:

- Simbol talijanskog fašizma fasces i dalje je ostao fasces. Danas prevladava izvorno značenje, tj. u većoj je mjeri simbol vlasti iz antičkog Rima nego fašistički simbol - nije dobio namjeravano ideološko-političko značenje, pa tako ni posljedično značenje. Uzroke možemo tražiti u relativnoj kratkoći trajanja talijanskog fašizma, činjenici da fasces nije uspio biti namet- 
nut kao državni simbol, ali i vizualne složenosti samog simbola (teško ga je rukom reproducirati).

- Svastika, odnosno nacistički kukasti križ, dobila je snažno ideološko-političko značenje, postala je općepoznati simbol nacizma i njegovih zločina, te time i snažno posljedično značenje. No u ovom slučaju oba su značenja različita od onog izvornog.

- Simboli komunizma, srp i čekić, crvena zvijezda i crvena boja, dobili su snažno ideološko-političko značenje, u slučaju crvene boje i petokrake zvijezde donekle podudarno s onim izvornim (arhetipskim), no usprkos tragičnoj bilanci posljedica komunizma još uvijek nemaju u percepciji velikog dijela javnosti odgovarajuće posljedično značenje.

Zbog onog što je za totalitarnih režima činjeno, bez obzira na sve napore uložene u proces njihova brendiranja, simboli tih režima trebali bi imati negativne konotacije (posljedično značenje). Naime, u procesu brendiranja presudna je činjenica da najsnažniju poruku o brendu šalju postupci samog brenda. Stoga su posebno negativne konotacije totalitarnih simbola među onim skupinama ljudi koje je neki totalitarni režim proganjao. Međutim, simboli nekih totalitarnih režima zabranjeni su ili nepoželjni u većini zemalja (fašizam, nacizam), a oni drugih (komunizam) još se uvijek slobodno ističu u nizu zemalja. Postavlja se pitanje zašto je tako, zašto promidžba ideja komunizma (iako u nešto „mekšem“ obliku) još uvijek traje. Možda je odgovor u činjenici da su zločini fašizma i nacizma javno osuđeni, a oni komunizma nisu. Iako na potrebu osude komunističkih zločina ukazuju neke europske rezolucije, komunistički simboli još se uvijek nesmetano koriste u EU. Tek u nekim zemljama (Mađarska, Poljska, Latvija, Litva, Ukrajina) zabrana korištenja tih simbola unesena je u zakone, ali provedba odredbi takvih zakona nailazi na osudu Europskog suda za ljudska prava jer se njome „krši pravo na slobodu izražavanja“.

\section{Literatura:}

Arbanas Kovačević, Barbara (2012), Povijest svastike. U: Matrix World. URL: https://matrixworldhr.com/2012/03/26/povijest-svastike/ (11.04.2017.)

Arendt, Hannah (1951). The Origins of Totalitarianism. New York: Harvest Book.

Armstrong, John A. (1961). The Politics of Totalitarianism. New York: Random House.

Berghaus, Günter (1996). Fascism and theatre: comparative studies on the Aesthetics and Politics of Performance in Europe 1925-1945. London: Berghahn Books.

Bernholz, Peter (2001). Ideocracy and totalitarianism: A formal analysis incorporating ideology. Public Choice, 108, 33-75.

Bracher, Karl Dietrich (1981). The Disputed Concept of Totalitarianism. U: Ernest A. Menze (ur.), Totalitarianism Reconsidered (str. 11-33). London: Kennikat Press.

Chevalier, Jean; Gheerbrant, Alain (1983). Rječnik simbola. Zagreb: Nakladni zavod Matice hrvatske.

Leach, Edmund (1976). Culture and Communication: The Logic by Which Symbols Are Connected. Cambridge, UK: Cambridge University Press.

Firth, Raymond (1973). Symbols: Public and Private. Ithaca, NY: Cornell University Press. 
Friedrich, Carl; Brzezinski Zbigniew, K. (1967). Totalitarian Dictatorship and Autocracy. Cambridge: Harvard University Press.

Gentile, Emilio (1996). The sacralization of politics in fascist Italy. Cambridge: Harvard University Press.

Gleason, Abbott (1995). Totalitarianism: The Inner History Of The Cold War. New York: Oxford University Press.

Griffin, Roger; Feldman, Matthew (2004). Fascism: Fascism and culture. New York: Routledge.

Heller, Steven (2008). Iron Fists: Branding the 20th Century Totalitarian State. London: Phaidon Press.

Hitler, Adolf (1993). Mein Kampf. Zagreb: Kvrga izdavaštvo.

Hoffer, Eric (2002). The True Believer: Thoughts on the Nature of Mass Movements. London: Harper Perennial Modern Classics.

Jung, Carl Gustav (1974). Čovjek i njegovi simboli. Zagreb: Mladost.

Kershaw, Ian (1992). The Nazi Dictatorship: Problems and Perspectives of Interpretation. New York: Arnold.

Khvostov, Mikhail (1996). The Russian Civil War (1) The Red Army: Men-At-Arms. Oxford: Osprey Publishing.

Kotler, Philip; Jatusripitak, Somkid; Maesincee, Suvit (1997). The Marketing of Nations: A Strategic Approach To Building National Wealth. New York: The Free Press.

Mack Smith, Denis (1989). Italy and its Monarchy. New Haven: Yale University Press.

Parkins, Wendy (2002). Fashioning the body politic: dress, gender, citizenship. New York: Berg.

Payne, Stanley G. (1996). A History of Fascism. London: Routledge.

Pipes, Richard (1995). Russia Under the Bolshevik Regime. New York: Vintage Books.

Sauer, Wolfgang (1967). National Socialism: totalitarianism or fascism? The American Historical Review, 73 (2), 404-424.

Schapiro, Leonard (1972). Totalitarianism. London: The Pall Mall Press.

Skoko, Božo (2004). Hrvatska — identitet, image i promocija. Zagreb: Školska knjiga.

Šimac, Neven (2011). Europa i komunizam. Nova prisutnost, 9 (1), 241-256.

Tatić, Danijel (2015). Svastika — čudan povijesni put prastarog simbola. U: Večernji list. Blogosfera. Viribus Unitis. URL: http://blog.vecernji.hr/danijel-tatic/svastika-cudanpovijesni-put-prastarog-simbola-735 (11.04.2017.)

Wharton, Christopher (2007). The Hammer and Sickle: The Role of Symbolism and Rituals in the Russian Revolution. U: Westminster College. Myriad. URL: http://www.westminstercollege.edu $/$ myriad/index.cfm parent $=2514 \&$ detail $=4475 \&$ content $=4797$ (04.04.2017.) 
The Perception of Totalitarian Symbols - The Visual Identity of Fascism, Nazism and Communism in Light of the Branding Process

\section{Predrag Haramija*}

\section{Summary}

The article examines the manner in which the symbols of the three totalitarian regimes, or rather ideologies of the 20th century (Fascism, Nazism and Communism) are perceived in light of marketing insights concerning the branding process. The symbols of totalitarianism have primarily been powerful propaganda and indoctrination tools, while the imposition of totalitarian ideologies can be discerned in its depth (and breadth) through the interrelationship between party and state symbols. The actions of totalitarian regimes and ideology enforcement practices affect a change in the original meaning of the symbols which they use. The symbols of totalitarian regimes today are therefore not viewed in light of their original meaning. Symbols of Fascism and Nazism are banned or are deemed undesireable in the majority of countries, while those of Communism are freely displayed in many lands. They are banned only rarely, the reason being that the crimes of some are publicly denounced, while those of others are not. Condemnation of actions committed under a particular symbol affects also its public perception.

Key words: totalitarianism, symbols, visual identity, promotion, branding

* Predrag Haramija, Ph.D., Zagreb School of Economics and Management. Address: Jordanovac 110, 10000 Zagreb, Croatia. E-mail: predrag.haramija@zsem.hr 